\title{
Abaeté, Rede de Antropologia Simétrica
}

\section{Entrevista com Márcio Goldman e Eduardo Viveiros de Castro}

\author{
entrevistadores Aristóteles Barcelos Neto, Danilo Ramos, Maíra \\ Santi Bühler, Renato Sztutman, Stelio Marras E Valéria Macedo
}

No final de 2004, dois professores do Programa de Pós-Graduação em Antropologia Social do Museu Nacional (UFRJ), Marcio Goldman e Eduardo Viveiros de Castro, idealizaram a Rede Abaeté de Antropologia Simétrica visando reunir pesquisadores de diferentes áreas e instituiçóes e promover discussóes antropológicas para além do ambiente de especialização que caracteriza o cenário acadêmico das ciências humanas na atualidade.

A melhor maneira de fazer funcionar essa rede, que embora esteja adensada no Museu Nacional não pretende ter uma sede fixa, foi a criação de uma página wiki, na qual é possivel desenrolar discussóes e produzir textos coletivos, (no sistema wiki, toda pessoa que acessa a página pode mudar o conteúdo do que lê, e todas as outras pessoas que acessam podem ver essas modificaçôes). O wiki Abaeté (http:/labaete. wikia.com) seguiu, nesse sentido, o exemplo do wiki Amazone (http:/lamazone.wikia.com), do Núcleo de Transformaçóes Indigenas (NuTI), coordenado por Viveiros de Castro. No wiki Amazone, Viveiros de Castro disponibilizou partes de um livro seu em preparação sob a forma de um texto-piloto, "A onça e a diferença". Seu objetivo era substituir o mar de citaçóes, do qual é composto um texto, por um processo de autoria coletiva capaz de dar margem a uma obra aberta.

A conexão entre campos semânticos - e também etnográficos - heterogêneos é justamente o alvo da rede Abaeté, e não surpreende que os campos evocados no Manifesto Abaetél digam respeito ao histórico de pesquisa dos idealizadores em questão. Viveiros de Castro é o que se pode chamar de "etnólogo". Pesquisou entre os Araweté, grupo de lingua tupi-guarani no sudeste do Pará, e já há mais de uma década se dedica ao estudo do que ele cunhou como "perspectivismo amerindio", modo de pensar que rejeita dualismos tipicos do pensamento ocidental-moderno. Já Marcio Goldman voltou-se à chamada "antropologia das sociedades complexas". Além de ter se debruçado sobre capitulos da história da antropologia, desenvolve suas pesquisas na cidade de Ilhéus (sul da Bahia), tratando de temas como participação politica, movimentos culturais e religioes afro-brasileiras.

Ao apostar na conectividade, Goldman $e$ Viveiros de Castro buscam diluir as fronteiras estabelecidas entre a "etnologia indigena" $e$ a "antropologia das sociedades complexas". Nesse sentido, eles atentam contra os "grandes divisores", estes

1. Disponível em http://abaete.wikia.com 
que separam em mundos incomunicáveis "nós" $e$ os "outros", produzindo não raro assimetrias do tipo "nós sabemos, eles crêem", "nós temos antropologia e filosofia, eles possuem crenças e visóes de mundo". Em vez des "grandes divisores", é preciso, eles alertam, pensar em "pequenas multiplicidades”. Em outras palavras, não se trata de abolir as diferenças entre os mundos, mas, a partir de conexóes transversais, capturar formas singulares de pensar e agir que podem ser traduzidas umas nas outras por meio de uma imaginação conceitual mais apurada.

A "antropologia simétrica", expressão cunhada por Bruno Latour, é então eleita como antídoto a esses "grandes divisores" na medida em que permite o estabelecimento de um diálogo não apenas entre áreas do conhecimento, mas entre mundos, por exemplo, o mundo ameríndio e o da ciência moderna. Afinal, se todos somos nativos, todos somos, de um ponto de vista reverso, antropólogos, como propôs Roy Wagner. Nessa dupla condição comum, e nessa possibilidade de transitar entre esses pontos de vista, é que se estabelece uma reflexividade propriamente antropológica, como sustentou Marilyn Strathern. Wagner, Strathern e Latour sáo considerados inspiradores da Rede Abaeté de Antropologia Simétrica. Seguindo os seus atalhos, fortemente criticos a uma antropologia standard, torna-se possivel aproximar os estudos sobre os "outros" e sobre "nós mesmos" de modo a desestabilizar os modelos teóricos dominantes $e$ enfatizar que o conhecimento antropológico não é jamais reflexo de um ponto de vista neutro ou total e só pode ser construido na interlocução com aqueles entre os quais se estuda.

$A$ idéia de que o conhecimento antropológico é construido em rede ressoa, enfim, na experiência de diluição da autoria. Como frisam Goldman e Viveiros de Castro, na entrevista que se segue e na qual as falas de ambos se encontram propositalmente fundidas, a internet e o wiki servem como instrumentos para a produção de um texto que é fruto de uma multiplicidade au- toral. $O$ autor deixa de ser Viveiros de Castro ou Goldman, individualmente ou em parceria, ou mesmo o conjunto de intervençóes realizadas por outros autores nos textos disponibilizados. $O$ autor passa a ser, então, a própria Abaeté, um "coletivo" ou "rede de associaçóes". Nesse sentido, como consta no texto-piloto, "Simetria, reversibilidade e reflexividade", Abaeté adquire o estatuto de um parlimpsesto, ela é um "objeto discursivo em situação de interpolação, enunciado por uma multiplicidade autoral antes que por autores múltiplos".

\section{Idéias}

A idéia da Rede Abaeté veio de uma experiência anterior feita por um de nós (Eduardo Viveiros de Castro): a tentativa de elaboração de um texto "coletivo" por meio da Internet. Tratase do Projeto AmaZone, que permanece ativo na rede, no endereço http://amazone.wikia.com/ wiki/Projeto_AmaZone. Esta página é ligada ao NuTI (Núcleo de Transformaçóes Indígenas), que reúne pesquisadores da área de etnologia indígena. Em função disso, aconteceram alguns encontros no Museu, em princípio para que esses pesquisadores apresentassem seus trabalhos. Mas aí aconteceu algo de relativamente inédito, ao menos no Museu Nacional: muita gente que não trabalha especificamente com etnologia se interessou pelos encontros e pelas discussóes. Imaginamos então, inicialmente, criar uma página parecida com a AmaZone, e, depois, tentar estabelecer uma rede, a Abaeté.

\section{Desconexóes, reconexóes}

A rede busca uma nova forma de conexão entre pessoas mais interessadas em pensar e discutir o que os antropólogos estáo efetivamente fazendo hoje do que aquilo se ensina como antropologia na universidade. Como observou 
Tim Ingold, a distância entre essas duas antropologias parece aumentar a cada dia. A forma rede é importante. Buscamos maneiras de criar conexóes que não se assemelhem ao modelo das associaçóes profissionais, ou do grupo de pesquisadores que se juntam para fazer um projeto, obter um financiamento etc. Esses modelos são perfeitamente normais e admiráveis, claro, mas será que não temos criatividade suficiente para usar o tipo de experiência que a antropologia suscita e promover outras formas de associação? Vários planos estão em jogo: as formas de associação, os modos de transmissão do saber e das experiências de cada um, o cruzamento de divisóes internas, e assim por diante. Nesse sentido, a fronteira entre as chamadas "etnologia indígena" e "antropologia das sociedades complexas" é particularmente perniciosa, porque tende a barrar esse tipo de conexão.

\section{Outras formas de associação: Wiki}

A Rede Abaeté pode ser tomada como uma espécie de "sujeito" distribuído, que teria por objeto ou objetivo algo como a elaboração de uma antropologia simétrica, tendo no wiki seu, digamos, método. As três coisas mantêm uma relação importante. $\mathrm{O}$ wiki Abaeté não é uma lista de discussão clássica da internet, em que tudo o que se tem a dizer é "sou contra" ou "sou a favor" disso ou daquilo. É preciso entrar no texto para modificá-lo. O resultado desse processo coletivo não é da mesma natureza de um trabalho individual, ou mesmo de um com vários autores identificados, onde o(s) autor(es) controla(m) o que vai ser publicado. A ferramenta wiki é para ser usada de uma maneira aberta a todo leitor. A enciclopédia Wikipedia (www.wikipedia.org) é o maior exemplo do sistema: uma enciclopédia em que todos podem entrar, escrevendo ou corrigindo o que quiserem. No caso da Rede Abaeté e do AmaZone, qualquer um que souber o endereço também pode entrar e modificar, mas a idéia é reunir pessoas interessadas (e, se possível, também interessantes), antropólogos ou congêneres. A nossa idéia é de fato borrar as fronteiras entre os autores, produzir uma certa multiplicidade autoral, mudar um pouco o regime de enunciação da produção antropológica, que é um regime clássico do autor individual (singular ou plural, pouco importa) que escreve um artigo ou livro e publica citando outros, os quais entram em seu texto unicamente através das aspas. A Rede Abaeté e o AmaZone buscam outras formas de conectar pessoas dentro de um mesmo discurso que não seja a forma das aspas, mas que envolva o outro na produção de um texto que não é mais individual. O que não quer dizer que é de todos, já que a diferença entre esse autor múltiplo e o mundo é grande. O texto não resulta de/em um consenso, pois a idéia é emitir proposiçóes radicais mas que não estejam assinadas por um autor e que nem caiam no regime do "ele disse e eu não concordo", mas que produza uma multiplicidade autoral, como resultado do trabalho de várias pessoas ao mesmo tempo. Se alguém fizer uma modificaçáo imbecil — um palavrão ou alguma coisa desse tipo — alguém entra e ao tira. Se alguém introduzir algo que traga uma contradiçáo teórica, qualquer um pode enviar uma mensagem para a página de discussão dizendo que a inserção tem de ser compatibilizada porque está afirmando o contrário da proposiçáo anterior, e assim por diante. $\mathrm{O}$ que fazer nesse caso? Uma nota dizendo que esta é uma posição específica de fulano, ou uma correção? A questão em si é parte do projeto. Enfim, há mil formas, mas o problema não é deixar aparecer contradiçóes ou muito menos escamoteá-las, e sim fazer sentido. A Abaeté tem um texto-piloto, Simetria, Reversibilidade e Reflexividade, inicialmente um manifesto que acabamos deslocando para uma página especial que não pode ser alterada, a fim de que ele permanecesse justamente como um manifesto, ou seja, uma referência. Ao mesmo tempo, expandimos o manifesto, tornando-o um texto-piloto que dia- 
loga com todas as outras coisas penduradas nesse wiki, coisas paralelas, ligadas, desdobradas a partir dele. É esse texto-piloto que deveria ser coletivamente modificado e elaborado

\section{Em rede}

Se o wiki é um instrumento de trabalho em rede, lembremos que a noção de antropologia simétrica surgiu num contexto teórico que também valoriza a noção de rede. De certo modo, foi Bruno Latour quem "inventou” a ambas ou, pelo menos, deu uma interpretaçáo que nos interessa para a noção de rede e para a idéia de uma antropologia de nós mesmos. Existe assim uma consubstancialidade primeira entre o Abaeté-wiki e a Abaeté-rede, e entre eles e o tema da antropologia simétrica. Esta, ao contrário de muitos mal-entendidos em circulação, opera, em parte, estabelecendo uma espécie de homologia formal entre os objetos que estuda e seu próprio modo de operação. $\mathrm{O}$ que corresponde, nesse sentido específico, a tomar esses objetos como redes de conexão entre humanos e não-humanos ou, em uma linguagem mais diretamente latouriana, em redefinir objetos que não podem mais ser definidos sob o modo da entidade, do sujeito ou do objeto purificados, da natureza ou da cultura purificadas, e assim por diante. Nessa perspectiva, os "objetos" são sempre articulaçóes entre dimensões, facetas, momentos diferentes, que nesse sentido, são múltiplos, ou melhor, são multiplicidades, quer dizer, são como a própria rede: nem um nem todos, mas todos menos um, n1 , isto é, a multiplicidade enquanto tal.

\section{Nem periférico nem central}

Por definição, a noção de rede é completamente refratária a qualquer diferença entre central e periférico. Uma rede não tem nem centro nem periferia, só pontos de adensamento. Por ora, o/a Abaeté é um/a wiki-rede em português, ou melhor, em brasileiro. Mas isso náo tem nada a ver com ser uma rede periférica, que, eventualmente seria capaz de se estender para o centro, uma rede que ou está dominada pelo centro, ou vai dominar este centro... Porque esta não é a questão! Lembremos a frase de Duchamp: "não há solução porque não há problema”. A existência da rede impede que esse problema se coloque enquanto tal. No caso da antropologia brasileira, a impressão que temos é que há uma densidade suficiente para se fazer um experimento desses: se nenhuma outra pessoa do planeta entrar na Abaeté - e não é esse o caso —, essa densidade já seria suficiente para que as coisas funcionassem. A distinçáo entre antropologia central e periférica é um fantasma que foi criado de propósito, e que serve para uma série de coisas. A Associação Brasileira de Antropologia, por exemplo, usa a distinção para obter algumas compensaçóes de associações mais "centrais"; alguns departamentos ou programas usam a distinção para indicar nomes ou organizar congressos ("agora o congresso tem que ser aqui porque somos a periferia e sempre somos discriminados..."); alguns criticam outros porque, supostamente, falam como se estivessem no centro quando estão na periferia; ao mesmo tempo, os mesmos críticos se angustiam perguntando se seremos ouvidos por pessoas fora daqui, como fazer para que eles nos leiam, e assim por diante. É preciso escapar desses falsos constrangimentos e colocar a verdadeira questáo: somos capazes de produzir idéias e de fazer algo novo com essas idéias? Do nosso ponto de vista, um dos problemas que enfrentamos atualmente é que as questóes organizacionais e de política institucional estão dadas de antemão, subordinando as questóes intelectuais substantivas (como vai se falar e não o quê ou sobre o quê vai se falar). Quando esse tipo de operação é praticada, já se assassinou o que há de mais interessante no nosso trabalho. 


\section{Pequenas Multiplicidades}

Para nós, foi curioso e, até certo ponto, surpreendente observar algumas reações ao que estamos tentando fazer. Alguns chegaram a dizer que pretendemos destruir a antropologia; outros (às vezes os mesmos) dizem que não há nada de novo nisso tudo; outros admitem que há algo de novo, mas ressaltam que não é a única coisa nova que existe na antropologia. Bem, claro que concordamos com essa última observação, mas achamos curioso que alguém considere necessário fazê-la; concordamos até com a idéia de que não estamos propondo nada de novo, uma vez que se alguém quiser procurar, certamente encontrará "precursores" e "influências" à vontade (só não entendemos muito bem por que alguém pode se interessar por isso); quanto à destruição da antropologia, tudo depende do que se entende por esse termo: se é de suas formas atuais de organização, poderia até ser; mas se é da antropologia enquanto aventura intelectual que se trata, e se quiséssemos ser pretensiosos, diríamos até que o que desejamos é tirá-la da estagnação em que, ao menos no Brasil, ela se encontra há alguns anos; mas é claro que não temos essa pretensão toda... O que parece particularmente irritante aos nossos críticos, se bem os entendemos (não fazemos questão absoluta disso, sejamos francos), é justamente a nossa tentativa de (re)aproximar a "etnologia indígena" da "antropologia das sociedades complexas", e nossa única hipótese sobre as raízes de tal irritação é que ela não respeita os feudos institucionalmente estabelecidos (outro dia ouvimos alguém falar, com aprovação, da necessidade de pagamento das "corvéias acadêmicas"...).

É preciso, pois, ressaltar que, em certo sentido, os textos que estão aparecendo nas páginas da Abaeté devem ser encarados a partir dos propósitos específicos ao qual se destinam. Não são textos publicáveis do jeito que estão em outro lugar. Por exemplo, a relação que estabelecemos entre Roy Wagner, Marilyn Strathern e Bruno Latour serviu aos propósitos de um manifesto. Se fôssemos escrever um artigo, essa relação seria elaborada de outra maneira, mas o texto-manifesto está elaborado desse jeito porque sua idéia foi aparecendo no cruzamento de várias coisas. A idéia de antropologia simétrica, de Latour, surgiu como o emblema mais óbvio de uma operação que buscava romper a separação entre os campos da etnologia indígena e o das chamadas sociedades complexas, sem negar suas singularidades. A questão que Latour coloca é o que significa fazer antropologia na nossa própria sociedade, questáo que ricocheteia sobre o modo de fazer antropologia em outras sociedades. Como fazer uma antropologia simétrica? Ou como simetrizar a antropologia? A noção de antropologia simétrica é alvo de todo tipo de mal-entendido porque a palavra simetria quer dizer muitas coisas diferentes. Quando Latour diz "simétrica”, o que ele propóe é a dissolução de assimetrias constitutivas do pensamento antropológico, pensamento cuja forma emblemática é a assimetria entre o discurso do sujeito e o do objeto. Assim, é contra essa assimetria que a noção de simetria é proposta. Ninguém está propondo um mundo onde tudo seria harmônico e igual! $\mathrm{O}$ oposto do grande divisor não é a unidade e a noção de simetria não vai restaurar nenhuma unidade perdida. $\mathrm{O}$ que se contrapóe aos grandes divisores são as pequenas multiplicidades. A noção de multiplicidade é a chave: o problema não é ser dois, mas ser só dois; e a solução para isso não é voltar ao um.

\section{Igualmente diferentes}

É evidente que as sociedades ou os coletivos não têm todos o mesmo poder, e o desafio da antropologia é posicionar os discursos da sociedade de que faz parte o antropólogo e aquela que ele estuda como igualmente diferentes, evitando a introjeção das relaçóes de poder em seu 
discurso. A simetria está nessas duas palavras, no igualmente e no diferente, ou seja, simetrizar não significa passar por cima do fato de que há uma diferença enorme entre as sociedades, mas, ao contrário, converter justamente esse fato no problema e fazer com que a sociedade ou o grupo de onde vem a antropologia seja tão antropologizável quanto os demais. Mas é preciso fazer isso sem tirar o antropólogo da jogada, porque é muito fácil exotizar os ocidentais, os brancos, o que for, desde que não seja exatamente onde você está. A insistência do Latour na antropologia da ciência — náo simplesmente na antropologia do discurso ocidental oficial, da razão ocidental dominante como um todo, mas da ciência especificamente - se justifica porque é aí que se enraíza a assimetria fundamental. Todo mundo é objeto, menos o sujeito. Eu sempre posso desobjetivar a mim mesmo, e o que nós estamos propondo é a possibilidade de bloquear essa clarabóia por onde o antropólogo desaparece. Assim, se é possível pensar a antropologia moderna a partir da relaçáo entre sujeito e objeto, e a pós-moderna a partir da relação entre sujeito e sujeito, uma antropologia que propomos denominar pós-social poderia talvez ser pensada segundo uma relação em que todos são sujeitos e objetos simultaneamente (como nos ensinam, aliás, tanto o perspectivismo nietzscheano quanto aquele de vários povos indígenas).

\section{Latour e a descolonizaçáo da antro- pologia}

É de se observar que Latour quase não se refere aos antropólogos profissionais. Fala de alguns, claro, mas ressalta que o que sempre o interessou na antropologia teria sido seu método, não seus conceitos, nem, muito menos, suas teorias. Não é difícil compreender essa posição de Latour se lembrarmos que uma das características da chamada antropologia das so- ciedades complexas sempre foi tomar conceitos tidos como tradicionais na antropologia das outras sociedades e aplicá-los à nossa. O problema é que um dos efeitos dessa operação (que poderíamos denominar falsa simetrização) costuma ser um enfraquecimento generalizado do que se está dizendo sobre nossa própria sociedade, uma banalização tanto do discurso antropológico quanto do objeto ao que ele está sendo aplicado. Latour, ao contrário, mais interessado em uma antropologia da ciência do que do cientista, é capaz de colocar sua ênfase nas práticas e não apenas nos discursos, ou melhor, em todos os tipos de práticas, discursivas e não-discursivas. $\mathrm{O}$ que significa que, na verdade, ele aplica o mesmo método que os antropólogos empregam para estudar casamentos, rituais, possessões etc. Descreve o que está efetivamente acontecendo quando alguém está fazendo ciência. Nesse sentido, se a antropologia sempre foi concebida como ciência de segunda classe, podemos ler o que Latour está propondo como uma descolonização da antropologia pela ciência.

\section{Wagner, Strathern e a desbanalização dos conceitos}

Por outro lado, nos últimos 25 ou 30 anos, no que ficou conhecido como pós-estruturalismo, foram aparecendo, no interior da própria antropologia, uma série de noções e de críticas a noçóes mais antigas que podem problematizar a opção latouriana pelo método antropológico em detrimento de seus conceitos e teorias. Essas transformaçóes já permitem, cremos, uma apropriação de noçóes da etnologia pela antropologia de nossa própria sociedade capaz de produzir efeitos de conhecimento, e não necessariamente de enfraquecimento ou de banalização, daquilo que se está dizendo e sobre aquilo de que se está falando. Por exemplo, a maneira como 
Wagner trata a noçáo de cultura como invenção ${ }^{2}$, ou a crítica de Strathern à noção de sociedade em favor da de socialidade. Essas duas noçôes, cultura e sociedade, se tornaram uma espécie de emblema da banalização em antropologia. Assim, quando Wagner reconceitualiza a cultura como uma operaçáo de invenção (em sentido completamente diverso do da "invenção da tradiçáa", anote-se), a idéia de cultura começa a se complexificar e a perder sua banalidade, porque a cultura só se constitui num certo ponto de contato, ela não "está lá”. Da mesma maneira, a noção stratherniana de socialidade só se constitui no funcionamento efetivo das coisas (humanos, animais, objetos, espíritos...), ela tampouco “está lá”. Em certo sentido, seria possível dizer que ao etnografar como os cientistas se relacionam para fazer ciência, Latour descreve seus modos de socialidade, assim como as invençóes que são obrigados a fazer para estabelecer relaçóes.

\section{Comunicabilidade das formulaçóes}

No caso específico de Marilyn Strathern, talvez pudéssemos dizer que sua hipótese ou sua questão fundamental seja a da comunicabilidade das formulaçóes. Por exemplo, seu livro mais conhecido, The gender of the gift $t^{3}$, tem duas partes, e ela procede como se jogasse uma contra a outra. De um lado, o discurso da antropologia feminista, de outro, o que os melanésios têm a dizer sobre aquilo que os antropólogos chamariam de gênero na Melanésia. O primeiro problema é: com que categorias podemos exprimir as categorias dos melanésios, quando, como diz a própria Strathern, por definição só temos à

2. WAGNER, Roy. 1981. The invention of culture. Chicago: University of Chicago Press.

3. STRATHERN, Marilyn. 1988. The Gender of the gift: problems with womem and problems with society in Melanesia. Berkeley: University of California Press. disposição nossas próprias categorias? Parecenos que uma das inovaçóes introduzidas por essa antropóloga é reconhecer que "nossas próprias categorias" é um objeto um pouco mais complicado do que parece. O problema levantado por Marilyn Strathern, diga-se de passagem, não significa nem que estamos fatalmente condenados ao etnocentrismo, nem a promessa de um ponto de vista e de um vocabulário "científicos" que ultrapassem, ao mesmo tempo, o nosso vocabulário e o deles melanésios. Pois, ao mesmo tempo em que o discurso radical do feminismo é, sem dúvida, um discurso da nossa sociedade, parece claro que não podemos dizer que ele seja o discurso dominante da nossa sociedade. Assim, em vez de simplesmente colocar em relação duas sociedades ou duas culturas, de acordo com o antigo método comparativo, Strathern coloca em conexão uma certa multiplicidade de práticas discursivas, o que permite que aquilo que se encontra entre os melanésios possa ser expresso de uma forma que certamente é "nossa”, mas que não é "nossa” no sentido de que é de todo mundo, que é apenas uma parte do que fazemos, uma parte que poderíamos denominar minoritária.

\section{Pessoas e coisas}

É preciso escapar das alternativas do tipo tudo ou nada, ou do que Isabelle Stengers e Philippe Pignarre chamam de "alternativas infernais". Podemos, por exemplo, partir de uma oposição muito simples: ali há uma sociedade de pessoas, aqui uma de bens ou coisas. Às vezes esses divisores podem ser bons pontos de partida... O chato é quando também são os pontos de chegada! Porque na chegada a questão não é constituir pessoas e coisas, mas perceber que pessoas e coisas, ou palavras e coisas, são apenas objetificaçóes de certas relaçóes, de certas tramas - e isso, claro tanto num caso quanto no outro. Dar voz às coisas náo quer dizer que 
as coisas sejam iguais às pessoas, mas que elas são iguais apenas na medida em que são resultantes de processos de objetificaçáo, processos que, não obstante, são heterogêneos e têm de ser descritos enquanto tais. Em Art and agency ${ }^{4}$, por exemplo, Alfred Gell procura definir os objetos como "agentes de segundo grau". Nesse sentido, continua separando humanos e nãohumanos, dessa vez como agentes de primeira e segunda classe. Gell, de certo modo, foi o autor que levou a antropologia social britânica a seu limite; é nesse limite que se pode situar a obra de Gell dentro de um projeto de antropologia simétrica pós-social. Sua idéia de que o objeto é, sobretudo, o índice de uma agência supóe no fundo uma distinção entre agência primária e secundária, isto é, uma distinção entre um sujeito vicário e um sujeito legítimo, já que é apenas na vizinhança deste que aquele pode adquirir agência. Haveria, assim, uma “ontologia dos agentes de verdade”, ou primários, e uma dos “agentes secundários”, que só são agentes quando colocados nas vizinhanças de um agente primário. Gell permanece, desse ponto de vista, dentro da visão naturalista cara à London School of Economics, supondo a existência de uma distinção natural entre agentes e coisas que, em seguida, é recoberta por uma (in)distinção social. Existiria uma diferença entre pessoas e coisas, ainda que em seguida as coisas possam ser trocadas como pessoas ou vice-versa. As pessoas são coisas secundariamente, e as coisas são pessoas secundariamente. $\mathrm{O}$ que, na verdade, não é muito diferente da distinção clássica em nosso direito entre pessoa física e pessoa jurídica. A pessoa jurídica é uma ficçáo legal, no sentido próprio do termo, porque a pessoa jurídica só é uma pessoa na vizinhança da pessoa física. É preciso que uma pessoa física responda pela jurídica, e, em última análise, não é possível arrastar para o

4. GELL, Alfred. 1998. Art and agency: an anthropological theory. Oxford, New York: Clarendon Press. tribunal uma pessoa jurídica independente de uma pessoa física. Ou seja, tudo é pessoa, mas algumas pessoas são mais pessoas que as outras. Lembranças de Radcliffe-Brown. Ora, basta um segundo para perceber que "pessoa física" é uma categoria jurídica, tão jurídica quanto a de pessoa jurídica. Não há "pessoas físicas" fora do direito. E aí?

\section{Instaurar uma multiplicidade}

No que diz respeito a Latour, um mal-entendido de que já falamos rapidamente é supor que, ao acusar e recusar os dualismos, seu projeto consistiria na restauraçáo de uma unidade do humano. $\mathrm{O}$ mundo dos híbridos, aquele que prova que ninguém jamais foi moderno, não seria o que uniria todos os homens, não seria o dado para todos os homens? O ponto é que separar vem sempre depois, é sempre a posteriori, não a priori. A purificação sempre vem depois, como a oposição entre natureza e cultura, à qual se chega mediante um processo laborioso de purificação, separação, destilação. Mas o que é dado é esse mundo do meio, da prática, anterior à distinção entre teoria e prática. Uma pergunta que, sim, poderia ser feita é se não seria impossível não purificar. E, nesse caso, como seria possível purificar de uma maneira não dualista, não polarizada? Ora, vencer (não se trata de ultrapassar) o dualismo não consiste em restaurar uma unidade perdida, mas em instaurar uma certa multiplicidade. O campo do meio - ou império do meio, como o chama Latour — é um campo de multiplicidade, disponível para toda a humanidade. No fundo o monismo mais radical sempre se encontra com a multiplicidade mais radical. Latour opera, cremos, em um registro mais contemporâneo que o dessas velhas questóes sobre unidade, dualidade etc. Continua a se repetir nas salas de aula de antropologia que o que define a disciplina é trabalhar com o problema da relação entre a unidade biológica do 
homem e sua diversidade sociocultural. É isso que as pessoas ainda estáo aprendendo quando começam a estudar antropologia. Mas o que isso tem a ver com o que os antropólogos estão efetivamente fazendo hoje?

\section{Alternância entre o dado e o constru- ído}

Há uma passagem em que Lévi-Strauss fala do sexo dos caracóis, que são hermafroditas. Se um caracol encontra outro caracol, quem vai ser o macho e a fêmea depende de uma série de circunstâncias, eles não são machos ou fêmeas a priori ou em si. Lévi-Strauss afirma que a distinção entre sentido literal e metafórico é como o sexo dos caracóis: se você olha daqui para lá, aquilo é letra e isso metáfora; se olha de lá para cá, é o contrário. Não existe metáfora em si, literalidade em si, significante em si, significado em si. Não são distinçôes essenciais, absolutas. É provável que algo próximo se dê na oposição entre o dado e o construído na semiótica de Roy Wagner: o dado é o que é pressuposto em função do que se usa como controle. Isso não quer dizer que, em outra circunstância, não se possa tomar o que se tomava como construído como dado e vice-versa. Ou que seja necessário dispor primeiro de um dado para que depois se tenha um construído: eles são simultâneos, estão em implicação ou pressuposição recíprocas. O que constitui uma espécie muito singular de dualismo, se quisermos manter o termo. Deleuze distingue, um tanto ironicamente, dois tipos de dualismo: um dualismo "verdadeiro" (de tipo cartesiano, onde se pode passar a vida inteira tentando conciliar o corpo e a alma ou coisas parecidas) e um dualismo que ele chama de "provisório", porque serve apenas como ponto de partida ou de apoio para outra operação, mais importante. Neste caso, há duas possibilidades representadas, para Deleuze, respectivamente por Spinoza e Nietzsche: de um lado, um monismo absoluto, de outro, um pluralismo absoluto. Apesar das aparências, isso náo constitui um novo dualismo porque, como sustenta Deleuze, o que isso revela é a identidade profunda entre Spinoza e Nietzsche, dois filósofos que todos achavam absolutamente opostos. E o que os identifica é o fato de tanto a unidade spinozista quanto a pluralidade nietzscheana serem da ordem da multiplicidade - conceito que abole os dualismos e todas os debates em torno do um e do múltiplo.

\section{Dualismos provisórios}

O ponto crucial é que o dualismo é mais um modo de tratamento das coisas do que uma maneira de distribuição "real" das coisas. Por isso, quando se diz, por exemplo, que as sociedades Jê são dualistas, é preciso ter cuidado para não cair nem na hipótese de que o dualismo é, no fundo, uma propriedade do espírito humano que os Jê (mas também Descartes e todo mundo) apenas exprimem a seu modo, nem na de que ele seria um traço substantivamente característico dos Jê, aquilo que os "identificaria" (em oposição aos Tupi, a nós mesmos etc.). Porque existe toda a diferença do mundo entre operar com dualismos substanciais e utilizar dualidades como pontos de passagem para se fazer outra coisa. O dualismo é uma forma de se administrar o Um (mesmo supondo o Múltiplo) ou um modo de sair da questão Um-Múltiplo para instaurar uma multiplicidade? Depende. Mesmo a separação entre corpo e alma pode ser usada para fins náo dualistas. $\mathrm{O}$ que, em geral, provoca aquelas críticas muito fáceis e algo irritantes: "você está sendo dualista!". Pior: "você é etnocêntrico! Você apenas projetou e/ou reencontrou o corpo e a alma dos cristãos!". Críticas não apenas simplistas como limitadoras, paralisantes. Pois o problema ("técnico", como diz a autora) é aquele enunciado por Strathern: "como criar uma consciência de mundos sociais diferentes quan- 
do tudo o que se tem à disposiçáo são termos que pertencem ao nosso"? Essa é a questão. Isso significa, cremos, que em Strathern nos deparamos sempre com esse tipo de dualismo provisório de que falávamos, já que suas análises em geral partem de distinçóes usuais para com elas fazer outras coisas.

Como fazer os conceitos de corpo e alma funcionarem de outra maneira? Se utilizarmos a noção de corpo e alma como um refúgio no qual se faz uma leitura cartesiana das noçôes indígenas, a crítica é totalmente legítima. Mas se tomarmos as palavras corpo e alma como tradução provisória dos conceitos indígenas e, em seguida, usarmos os conceitos indígenas para sabotar os conceitos ocidentais de corpo e de alma, essa homonímia se faz estratégica e a coisa se torna interessante. Traduzimos as palavras, mas preservarmos a dinâmica conceitual nativa e assim, quem sabe, conseguimos perturbar nossas próprias categorias, mostrando que alma e corpo sáo capazes de outras coisas. Toda discussão de Strathern sobre o feminismo tem a ver com isso. Ao contrário de muitos antropólogos, Strathern foi realmente afetada, no bom sentido do termo, pela crítica pósmoderna, ou seja, em vez de perder seu tempo acusando os equívocos ou as bobagens dos pósmodernos, ela concentrou seu foco em uma questáo que eles levantaram mas com a qual não souberam lidar muito bem: como falar dos outros sem que se esteja falando de si mesmo. A reposta de Strathern é que mesmo que essa proeza seja impossível, isso não significa o silêncio - bem ao contrário do que supunham os próprios pós-modernos. Se, ao falar dos melanésios, necessariamente usamos categorias que são nossas, é preciso proceder de um modo em que os melanésios nos ajudem a nos distanciarmos dessas nossas categorias. E este é o sentido, mais alargado que o de Latour talvez, que gostaríamos de dar à idéia de antropologia simétrica. Não se trata simplesmente de incluir na análise a ciência e a política ocidentais e proceder como os antropólogos que analisam as sociedades não-ocidentais. $\mathrm{O}$ desafio maior é tratar nossos conceitos com a mesma dureza com que tratamos os conceitos dos outros - e com a ajuda dos conceitos dos outros! Aquilo que os nossos conceitos faziam com os dos outros, agora eles também vão sofrer a partir dos conceitos dos outros.

\section{Comparar o incomensurável}

Pode-se argumentar, claro, que esse novo método comparativo não está comparando coisas comparáveis, mas bananas e laranjas, segundo a velha metáfora até hoje empregada nos cursos de introduçáo à antropologia. Mas, por que comparar o comparável? Para isso basta chamar um contador... O interessante é medir o incomensurável, comparar o incomparável, como disse Marcel Detienne (em um livro justamente chamado Comparer l'incomparable'). $\mathrm{O}$ que quer dizer isso, o incomensurável? Ora, o que não tem uma medida comum. A noçáo de comensurabilidade supóe que o que comensura duas coisas está fora delas. Duas coisas são comensuráveis em função de uma terceira, que é supostamente a natureza em si. Esta funciona como o referente que legisla de que modo $A$ está ligado a $B$ em função de uma terceira coisa que é independente dela. Achamos que uma das coisas que a antropologia mostra é que a comensurabilidade é um processo interno, não externo. $\mathrm{O}$ metro padrão, para usar uma linguagem latouriana, deu muito trabalho para ser elaborado. Com que metro você mede o metro padrão? Como é que você vai saber que existe um metro, o metro padráo? Se existe alguma coisa incomensurável é precisamente o metro padrão, porque ele é a medida de todas as coisas. Pensando de novo em The invention of

5. DETIENNE, Marcel. 2000. Comparer lincomparable. Paris: Seuil. 
culture, de Roy Wagner, poderíamos dizer que a noção de cultura é problemática sempre que se pretende que ela funcione como um metro padráo. Por outro lado, ela pode ser reinventada se se admite que ela é apenas um meio de comparar o incomensurável.

\section{Relação versus identidade}

Vale a pena observar que Wagner utiliza muito a palavra relatividade, mas, salvo engano, nunca relativismo. De fato, é preciso ativar essa pequena dicotomia porque, de certo modo, o relativismo já é uma maneira de domesticar a relatividade. Como diria Deleuze, o relativismo é a idéia de que a realidade é relativa, e a relatividade é a idéia de que o relativo é que é verdadeiro. Que a verdade do relativo é a relação. $\mathrm{O}$ que significa que não há não-relação nesse sentido específico. Isso de algum modo conecta esses três autores, Latour, Strathern, Wagner (além de Deleuze, Guattari e outros de quem gostamos). Eles estáo todos na contramão de uma visão identitária da relação, essa visão que os cientistas sociais apresentam todos os dias no jornal e na televisão. Porque, dizem eles, essas são idéias "perigosas": ao enfatizar as diferenças, temos a guerra, a destruição, porque se está. E, de fato, quando se supóe que só existam identidades que se relacionam, as únicas formas de relação passam a ser a assimilação ou a destruição. Uma teoria verdadeiramente relacional, que náo suponha identidades existindo a priori ou em si, não tem nada a ver com isso. $\mathrm{O}$ que se vende por aí são teorias identitárias da relação (identidade contrastiva, etnicidade - Barth, em suma). É como se a relação existisse para a identidade. Antigamente se imaginava que primeiro existiam as identidades e entáo as relaçóes; agora se diz que "as identidades sáo relacionais", como se as relaçóes existissem para produzir as identidades. Não se progrediu muito, pois tudo continua existindo apenas para terminar em uma identidade. Ou, como dizia Mallarmé: o mundo existe para terminar num livro. Triste destino da relação. É claro que as relaçóes produzem, entre outras coisas, identidades. Mas não devemos imaginar que as relaçóes existam para produzir identidades, que é esse seu telos, seu objetivo, sua finalidade. (Como se toda diferença quisesse "no fundo" ser uma identidade). Esse é o problema. A impressão que se tem é que essas noçôes de identidade, como as que derivam das abordagens das "relaçóes raciais" ou das "relaçóes interétnicas", agem como uma máquina de repressáo contra qualquer outra coisa que se deseje pensar. É como se todos soubessem a resposta de antemão. Seria preciso, antes de mais nada, saber o que se quer dizer com a palavra identidade. Ou melhor ainda, o que se pretende náo dizer, ou o que náo se deseja que se diga, ao empregar essa noção.

\section{Alteridade e alienaçáo}

Se identidade existe, ela é secundária em relação à alteridade. Mas é também preciso cuidado para não transformar a alteridade em outra identidade. A alteridade hoje em dia costuma aparecer como meio para a afirmação da identidade. Uma boa alternativa vocabular, mas que infelizmente já foi usada para fins completamente opostos, seria a palavra alienação, nome, a rigor de uma ação e não de um estado, como "alteridade". Mas a palavra foi destruída pelo uso inverso ao que buscamos: alienação é perda de identidade. Observemos de passagem que identificação, sim, também é um processo, e um processo bem interessante, uma vez que existe uma imensa quantidade de dispositivos sociopolíticos de identificação - por exemplo, vários conceitos antropológicos...

\section{A perversão identitária}

Todas as etnografias bem elaboradas, nos mais diversos campos, mostram que, além de extremamente sofisticadas, as teorias locais são 
hábeis e flexíveis. E que o discurso da identidade aparece sempre que o Estado entra em cena, para o bem ou para o mal, se podemos nos exprimir dessa forma. Como não pretendemos fazer parte do aparelho de Estado em nenhuma de suas múltiplas formas, perguntamos de que lado está o antropólogo nessa história. Do lado do Estado, para dialogar com ele ou em nome dele? Ou a tarefa mais interessante da antropologia não seria justamente encontrar um modo de se conectar com essas outras formas, mais instáveis, de articular as relaçóes? Essa é uma aposta política e teórica. $\mathrm{Na}$ antiga teoria da luta de classes, em que os campos são determinados pela posição que os atores ocupam nas relações de produção, proletário era proletário e burguês era burguês (se abstrairmos, claro, essas coisas meio estranhas que eram a pequena burguesia, a classe média etc.). Mais tarde, começaram a aparecer os movimentos identitários, porque a classe como categoria objetiva desapareceu, ou se tornou complicada porque as relaçóes de produçáo se tornaram incrivelmente complexas, e a noção de classe foi ficando cada vez mais difícil de ser determinada. Então, no lugar da luta de classes, passamos para a reivindicação de identidades.

Uma das coisas curiosas sobre a noçáo de identidade é que é muito diferente se identificar e ser identificado. Normalmente achamos que é a mesma coisa, como na definição clássica adotada pelo Estatuto do Índio: "índio é aquele que se identifica e é identificado como tal". Nesse pequeno "e" reside toda a confusáo. Ao mesmo tempo é identificado? Ou alternativamente é identificado? Por quem é identificado? Quando? Em que circunstâncias? O que acontece quando alguém se identifica e não é identificado, ou quando é identificado e não se identifica? Quando te identificam, é uma objetivação, para o bem ou para o mal: "você é brasileiro", te identifica alguém, o que imediatamente retira de você tudo o que interessa. Ou, "você é judeu", "você é gay”, qualquer coisa. Quando alguém come- ça a dizer "sim, sou negro e me orgulho disso" ou "sim, sou gay, exijo tais direitos", "sim, sou brasileiro", alguma coisa sutil começa a acontecer. Normalmente, quando alguém começa a se identificar com aquilo que por meio do qual o identificam, ele passa a identificar alguém no seu lugar. Ele vai inventar o palestino, no caso do judeu; vai inventar um argentino, no caso do brasileiro (brincadeira...). Ou seja, vai inventar alguma coisa "pior" do que ele. Parece, assim, que a identidade possui a perversa capacidade de produzir esses efeitos em que o sujeito começa a aprisionar a si mesmo e aos outros. "Assumir" sua identidade é apenas o primeiro capítulo de um processo que aparece como "luta de libertação": "sim, sou isso e me orgulho disso". Mas, logo depois, começa a crescer o germe microfascista que já estava lá, e se eu me orgulho disso, alguém tem que se envergonhar: quem é que vai se envergonhar no meu lugar? Quem é que eu vou identificar agora?

\section{Paradoxos da indianidade}

Esse movimento de identificação é curioso porque ele nunca vai até o fim, ao menos da forma em que começa: em algum momento ele tem que parar ou ser detido. Vejamos, por exemplo, o caso clássico do Nordeste, dos índios "emergentes" do Nordeste. Trata-se de um paradoxo do ponto de vista conceitual: os índios do Nordeste são "mestiços", eles são a encarnação viva da anti-idéia de índio puro, com tudo o que há nela de racista, essencialista, culturalista etc. Desse modo, o índio do Nordeste é um índio bom, no sentido metafísico da palavra, pois estaria encarnando a essência da não essencialidade, a essência do não-culturalismo. $\mathrm{O}$ que acontece quando os índios do Nordeste são reconhecidos como índios pelo Estado? Eles poderiam tentar fazer valer diretamente a legitimidade da mestiçagem como condição, mas o que ocorre é, antes, o contrário. 
Eles começam a distinguir quem é índio puro e quem não é, dizendo: "você não pode ficar aqui porque você não é índio puro". Um índio diz para outro índio: "nós somos os verdadeiros Pancararu, vocês são mestiços"; "índio mesmo somos nós aqui"; "olha, o Estado reconheceu a comunidade Pancararu, você não é Pancararu, você é mestiço, tem que ir embora”. E aí o próprio Estado - e mesmo alguns defensores não-governamentais dos índios — dizem que é preciso fechar a lista de quem é índio (ou quilombola ou o que quer que seja) para evitar uma confusão generalizada. Ou seja, o Estado e seus congêneres impóem o congelamento do processo que eles mesmos haviam gerado.

\section{Identidade, isso pega?}

Uma das sessóes de debates que organizamos na Abaeté tinha esse título: "identidade, isso pega?". Chegamos à conclusão de que pega. Como é possível abrir mão da noção de identidade quando se estrutura toda a ação em torno dela? Os militantes do movimento indígena ou do movimento negro adotariam, então, o que se convencionou denominar "essencialismo estratégico". Noção cínica e paternalista, que "perdoa" os oprimidos por seus erros teóricos. Mas não é esse o problema. O problema é o preço político que se paga por esse uso abusivo e quase monoideístico da noçáo de identidade. Por que imaginar que todas formas de luta passam necessariamente pela noção de identidade? Obviamente há outras. O que tem que ser enunciado é uma coisa muito elementar: por que alguém que habita um lugar há centenas ou milhares de anos só tem direito de viver em paz aí se for índio ou se for negro? Por que é preciso passar por processos de reconhecimento como índio ou quilombola para que se tenha o direito de viver do jeito que se quer? É assim que a identidade pega! Ninguém adere por "conscientização" e nós sabemos, histórica e etnograficamente, como é que a identidade pega: ela é aceita e incorporada por falta de opção!

\section{Criando entidades}

Toda identidade supóe uma entidade, toda identidade engendra uma entidade que vai administrá-la segundo o modo de constituição e funcionamento do Estado. Porque uma das maiores e mais pérfidas habilidades do Estado é sua capacidade de convencer todo mundo de que a única maneira de enfrentá-lo é assumindo sua forma (com outro conteúdo, claro, mas quem se importa?). No que diz respeito aos antropólogos, nossa questão não é só conceitual, ela também é política. Estamos fabricando idéias, fabricando conceitos que se vinculam a esse tipo de operação. É curioso comparar um laudo de reconhecimento de uma terra de quilombo ou indígena e, por exemplo, à tese que o autor desse hipotético (mas é claro) laudo escreveu sobre o mesmo lugar. $\mathrm{Na}$ tese, o autor é sempre um desconstrucionista ou, mais precisamente, um crítico que vai desnaturalizar e desestabilizar todas as falsas certezas. Mas, no laudo, o autor vai essencializar, assumindo para si a operação do essencialismo estratégico. É um enigma como alguém consegue fazer essas duas coisas ao mesmo tempo. Como é possível pintar, com a mesma tinta, um retrato de desessencializaçáo e outro de objetificação? É possível sim, porque no fundo trata-se da mesma operação, apesar de parecerem duas operaçóes diferentes. Assim, vive-se no melhor dos mundos, ganhando algum dinheiro para identificar gente e, ao mesmo tempo, conseguindo títulos acadêmicos ao desindentificar a mesma gente. Isso só vai se complicar quando os advogados de madeireiras, mineradoras e congêneres começarem a usar as teses para refutar os laudos (como, aliás, já acontece em outros países).

\section{Texto e autor híbridos}

Todos sabemos que a antropologia não pode 
se definir por um objeto. As questóes de pesquisa devem ser propriamente intelectuais e não ficar à mercê das ondas e políticas de financiamento. Se é importante estar atento à sociologia da produçáo intelectual, coisa que evidentemente existe e que todo mundo sofre na pele, mais importante é saber que tem gente que não acredita que isso seja a coisa mais importante do mundo. A pesquisa náo pode ser escolhida e orientada apenas por "demandas de balcão", nome técnico desse tipo de coisa. De que alternativas dispomos? Acreditamos que uma possibilidade é a criação o mais livre possível de territórios e espaços onde se possa pensar com mais prazer. Assim, a idéia da Abaeté tem esse componente associativo-institucional, ou melhor, contra-associativo e contra-institucional. Tem uma dimensão teórica, que é a questão da antropologia simétrica. E tem uma dimensão técnica, que é a questáo inovadora, quer dizer, a tentativa de usar o instrumento wiki para efetuar uma comunicação subordinada a uma produção inovadora e livre. Ou seja, não se trata apenas de circulação de idéias, mas de produçáo de idéias. Como utilizar esse sistema de circulação - que não obedece ao modelo clássico dos seminários e dos artigos autorais (que são ótimos e vão continuar existindo) - para abrir um novo espaço de produção de textos híbridos, múltiplos, de vários autores? Nesse espaço, quem escreve não deve mais ser a questão. Trata-se de deslocá-la para $o$ que se escreve, de modo que o quem se torna progressivamente menos importante ou importante em contextos específicos. Sabemos que isso não é fácil, inclusive porque suspende antigos referenciais, como todo o complexo em torno da autoria. Sabemos que náo são raros aí os bloqueios pessoais, o que exige primeiro, e evidentemente, uma escolha e, depois, muita autodisciplina. Como isso começou há pouco tempo e, de certa forma, de modo meio espontâneo, não sabemos ainda muito bem aonde é que esse negócio pode chegar - nem mesmo se ele vai chegar em algum lugar.

\section{Saída transversal pela esquerda}

De toda forma, o que pretendemos é desenvolver conexóes transversais. "Transversalidade" é uma noção que Guattari desenvolveu e que se opóe tanto a verticalidade quanto a horizontalidade. No primeiro caso porque é preciso escapar dessa relação mestre-discípulo, que é uma relação basicamente vertical. No segundo, porque não se deve supor que é possível ligar qualquer coisa com qualquer coisa, pois há coeficientes de transversalidade. Às vezes a conexáo funciona, às vezes não funciona, é uma questão de experimentação. Essa idéia permite, também, conectar diferentes teorias. $\mathrm{O}$ uso que alguns antropólogos fazem, por exemplo, da obra de alguns filósofos (como os próprios Deleuze e Guattari) implica essa transversalidade. Há sempre uma certa aspereza, há sempre transformaçóes a introduzir, mas essas diferenças não são, em princípio, obstáculos para as conexôes que se pretende estabelecer. As relaçôes transversais são as únicas capazes de gerar e sustentar um "grupo-sujeito", capaz de não se submeter passivamente nem às determinaçóes exteriores, nem à sua própria lei interna. Esta é, parece-nos, a única saída pela esquerda para 